\title{
Role suverenity při analýze vztahu Evropské unie a České republiky jako členského státu EU - slepá větev, nebo odrazový můstek?*
}

\section{Role of Sovereignty Concerning Analysis of Relationship Between the Czech Republic as a Member State of the EU and the Union Itself - Dead Branch or Stepping Stone?}

\author{
Miroslav Knob ${ }^{* *}$
}

\begin{abstract}
Abstrakt
Clánek navazuje na závěry kniby Pavla Molka Materiálni obnisko Ústavy: Věcný limit evropské integrace? Ve svém qákladu stavi na její analýze materiálního obniska Ú stavy a pojmu suverenity v nèm. Článek. nejprve analyzuje základni prǐstupy k pojmu suverenity predevšm ve və̨tabu k problematice práva Evropské unie a vątahu EU a členských státu. Článek dále analyzuje roz̧hodovaci praxi Ústavního soudu v šesti podstatných judikátech, které se dotýkaji vątahu Evropské unie a Ceské republiky jako jejího členského

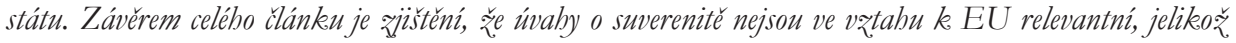
suverenita je spǐse limitaci tohoto procesu, ně̌jeho podstatným prvkem. Pokud se dalši akademická debata chce zabývat vżtaby EU a členských státu z pobledu federalizačnich teorií, je nutné se zamèrit na problematiku prenosu pravomocí.
\end{abstract}

Klíčová slova

Europská unie; suverenita; prènos pravomocí; Ústavní soud.

\section{Abstract}

This paper builds on the conclusions of Pavel Molek's book, „Material Core of Constitution - an Eternal Obstacle to EU Integration?" Basics of this paper are based on the book's conclusions regarding the concept of material core of the constitution and the concept of sovereignty as a part of the material core of the constitution. The article first analyses basic approaches to the concept of sovereignty, especially focusing on the issue of European Union law and the relationship between the EU and its Member States. The article further outlines six substantial judgements of Constitutional court and the role of the concept of sovereignty in relationship between the Czech Republic as a member state of the $E U$ and the Union itself. The conclusion of this paper is the finding that concept of sovereignty has no relation to the analyzation

\footnotetext{
Pracovní verze tohoto článku (která však doznala značných změn) byla publikována v rámci Law MUNI Working Papers. Dostupné z: http://workingpapers.law.muni.cz/content/cs/issues/. Za kritické poznámky a prripomínky děkuji Ladislavu Vyhnánkovi, Pavlu Molkovi, Janu Svatoňovi a především Robertu Zbíralovi. Veškeré prúpadné chyby v textu zůstávají pochopitelně moje vlastní.

** Miroslav Knob, doktorand, Katedra ústavního práva a politologie, Právnická fakulta, Masarykova univerzita, Brno / Ph.D. student, Department of Constitutional Law and Political Science, Faculty of Law, Masaryk University, Brno, Czech Republic / E-mail: mirek.knob@gmail.com
} 
of the relationship between the Czech Republic as a member state of the EU and the Union itself. That is because the sovereignty is more a limitation for this relationship than its part. If the next academic debate wants to deal with relations among the EU and its Member States, it is necessary to focus on the issue of transfer of competences.

\section{Keywords}

European Union; Sovereignty; Transfer of Competences; Constitutional Court.

\section{Úvod}

Cílem následujícího článku je reflektovat a následně uzavř́it akademickou debatu ve vztahu k úvahám ohledně suverenity jako prvku podstatných náležitostí demokratického právního státu v kontextu prohlubující se evropské integrace z pohledu českého ústavního pořádku. Respektive cílem tohoto článku je navázat na závěry nedávné knihy Pavla Molka pojednávající o problematice materiálního jádra ústavy a podstatných náležitostí demokratického právního státu ve vztahu k evropské integraci a argumentovat, že ve vztahu k dalším úvahám o povaze vztahu Evropské unie a jejích členských států je operování s pojmem suverenity z akademického hlediska uzavřeno a nepřináší do debaty nic nového. Tento závěr je opřen o analýzu chápání pojmu suverenity ve vztahu k právu EU v relevantní judikatuře Ústavního soudu.

Ve svých úvahách se zaměřím na roli suverenity v rozhodovací praxi Ústavního soudu ve vztahu $\mathrm{k}$ případům, ve kterých se Ústavní soud zabýval právě vztahem práva Evropské unie a České republiky. Cílem článku bude na základě této rozhodovací praxe analyzovat roli suverenity ve vymezení tohoto vztahu, tedy nakolik je potřeba v rámci výzkumu, který se bude zabývat problematikou vztahu práva EU a právních řádů členských států, konkrétně České republiky, zaobírat prvkem suverenity. Předpoklad, který se článek na základě analýzy relevantní rozhodovací praxe Ústavního soudu České republiky snaží potvrdit, je, že faktor suverenity je ve vztahu k analýze tohoto vztahu do značné míry irelevantní.

Článek se ve své první části zaměří na nástin konceptu suverenity jako prvku materiálního jádra ústavy, přičemž v této části bude text vycházet z tezí Pavla Molka, které uvedl ve své knize Materiální obnisko Ústavy: Věrný limit evropské integrace? Další část textu se bude sestávat $z$ analýzy relevantní judikatury Ústavního soudu, na kterou budou navazovat závěrečné úvahy.

1 MOLEK, Pavel. Materiální ohnisko ústavy: věcný limit evropské integrace? 1. vyd. Brno: Masarykova univerzita, Právnická fakulta, 2014, 284 s. Spisy Právnické fakulty Masarykovy univerzity, raada teoretická, Edice Scientia, sv. č. 488. ISBN 978-80-210-7453-4. Kniha je také dostupná online na https://munispace.muni. cz/index.php/munispace/catalog/book/620 


\section{Východiska pro úvahy o materiálním jádru Ústavy}

Kniha Pavla Molka Materiálni ohnisko Ústavy: Vếný limit evropské integrace? pro mne představovala ono cimrmanovské „ted’ tu byl“2. Ve své monografii se Pavel Molek vypořádal s problematikou materiálního jádra Ústavy z pohledu evropské integrace a role České republiky v ní. Toto téma je částečně předmětem mé disertační práce, již píši na katedře ústavního práva a politologie Právnické fakulty Masarykovy univerzity pod vedením docenta Jana Svatoně.

$\mathrm{V}$ následujících úvahách je $\mathrm{v}$ prvé řadě potřeba vyjít $\mathrm{z}$ důsledného oddělení nezměnitelných náležitostí ústavy (tedy „klauzule věčnosti`) a materiálního jádra ústavy³. Pojem nezměnitelných náležitostí označuje ustanovení, o kterých sama ústava tvrdí, že je nelze měnit ${ }^{4}$, zatímco materiální jádro ústavy představuje samotné základy ústavy (její statiku $)^{5}$. Toto oddělení obou pojmů je pro následující úvahy podstatné s ohledem na znění článku 9 odst. 2 Ústavy, dle kterého „,[Z]mèna podstatných náležitosti demokratického právního státu je nepř̈pustná. "Jako nezměnitelné tedy český ústavodárce označil „,podstatné náležitosti demokratického právního řádu“, což je pojem odlišný od „materiálního ohniska ústavy“, které tvoří základní stavební konstrukci ústavního pořádku České republikyº . Jak uvádí Pavel Molek (přičemž článek z této teze vycházî), pojem suverenity je jedním z prvků, které ukazují, nakolik je potřeba rozlišovat oba pojmy. Zatím co suverenita není podstatnou náležitostí demokratického právního státu ${ }^{7}$, jedná se o součást materiálního jádra Ústavy. 8

Pavel Molek ve svých závěrech nabízí dvě cesty, jak v prrípadě posunu EU do podoby federálního státu překlenout fakt, že je suverenita České republiky jako státu součástí materiálního jádra ústavy ČR. První možností, kterou kniha Pavla Molka nabízí, je přijmout zcela novou, federální, ústavu. Lid jako originální ústavodárce by přijal zcela novou ústavu, odlišnou od té současné, součástí jejíhož materiálního jádra by byla povaha České republiky jako státu federální Evropy9 . Druhou možností je postupná proměna

2 Scéna z filmu „Jára Cimrman, ležžici spici“" ve které je Jára Cimrman předběhnut se svými vynálezy u patentového úřadu jinými génii své doby, jako Bellem, Edisonem či Nobelem, se mi u knihy Pavla Molka pochopitelně vybavila z toho důvodu, že vím, nakolik je humor fiktivního českého génia Pavlovi blízký.

3 MOLEK, 2014, op. cit., s. 137 a násl.

4 MOLEK, 2014, op. cit., s. 138.

5 MOLEK, 2014, op. cit., s. 138.

6 MOLEK, 2014, op. cit., s. 137 a násl.

7 MOLEK, 2014, op. cit., s. 228.

8 MOLEK, 2014, op. cit., s. 234.

9 Byt' Pavel Molek ve své knize výslovně nezmiňuje kořeny této úvahy, vychází zde z teorie společenské smlouvy a teorií moci ustanovené a ustavující. Pro podrobnější pojednání o filosofických kořenech smluvních teorií srovnej BAROŠ, J. Cesty k suverenitě lidu: nástin genealogie jednoho konceptu. Časopis pro právni vědu a praxi, roč. 2013, č. 1, s. 1-10. 
statiky ústavy (tedy jejího materiálního jádra), která bude navazovat na postupnou proměnu EU (můžeme říci její federalizaci). Podstatný prvek tohoto druhého řešení je skutečnost, že proměna EU je postupný proces, který nebude probíhat skokově (např́iklad vyhlášením „Spojených států evropských“ a jejich nové ústavy), ale bude probíhat postupně, spolu se stále těsnější integrací jednotlivých států Unie (prričemž přijetí nové ústavy „Spojených států evropských“ by mělo představovat završení tohoto vývoje).

Právě druhý navržený postup v knize Pavla Molka je ústředním předpokladem tezí tohoto textu. Jelikož proces skokové integrace je v současné době z hlediska politické reality nepředstavitelný, nemají úvahy tímto směrem př́liš nosný charakter a je potřeba se zaměřit právě na proces postupného prohlubování integrace. Z akademického hlediska je proto potřeba hledat metody, jak tento postupný proces zachytit a akademicky popsat. Proto je potřeba se vypořádat s otázkou, jakou roli v tomto procesu sehrává suverenita, která je součástí materiálního jádra Ústavy, a nakolik se tedy akademická debata má na tento koncept zaměřit.

\section{Nástin konceptu suverenity}

Před samotnou analýzou relevantní rozhodovací praxe Ústavního soudu je potřeba pojednat o tom, co se rozumí pod pojmem suverenita, jelikož bude středobodem dalších úvah v článku. Co tedy pojem suverenita znamená? Základní definice suverenity zní: „Stát je suverén, pokud neni podř́zen žádné moci, vnitřni, ani vnèjsisi"no. Tato teorie je však značně zjednodušující a popravdě - celý problém spíše problematizuje, než aby do něj vnesla jasné kontury. Debata o suverenitě bývá navíc často ideologicky zabarvena ${ }^{11}$, samotná debata se tak často netočí kolem problémů právní teorie, ale spíše politické filosofie, kdy si každý z účastníků debaty vybírá ty aspekty, které se mu hodí pro objasnění jeho pohledu na problematiku suverenity.

Další možnou definicí suverenity, již je možné nalézt v české státovědné literatuře, lze založit na výsostné povaze státní moci, která sama o sobě svědčí o její suverenitě. ${ }^{12}$ Výsostnou povahou státní moci se dle této definice rozumí „(1) jeji nezávislost na jiné státní moci, respektive verejejé moci jiných institucí, (2) výlučnost, neboli faket existence jedné (jednotné) státni moci a (3) neomezenost z blediska uplatňováni" ${ }^{13}$

10 ROSENFELD, Michel a András SAJÓ (eds.). The Oxford bandbook of comparative constitutional law. 1st ed. Oxford, U.K.: Oxford University Press, 2012, s. 359.

11 ROSENFELD, SAJÓ (eds.), op. cit., s. 351; na př́kladu debaty v České republice tento jev popisuje Jiř́ Břibáň v PŘIBÁŇ, Jiř́. The semantics of constitutional sovereignty in post-sovereign „new“ Europe: A case study of the Czech Constitutional Court's jurisprudence. International Journal of Constitutional Law, 2015, vol. 13, no. 1, s. 180-199.

12 FILIP, J., J. SVATOŇ a J. ZIMEK. Základy státovédy. Brno: Masarykova univerzita. 2007, s. 41.

13 FILIP, SVATOŇ, ZIMEK, 2007, op. cit., s. 41; shodně MEYER, G. a G. ANSCHÜTZ. Lebrbuch des deutschen Staatsrecbts. 8. Aufl., unveränderter Nachdruck der 7. Aufl. Berlin: Duncker \& Humblot, 2005, s. 24. ISBN 3428120000. 
Jedním z možných východisek, jak překlenout rozdílné chápání pojmu suverenita je důsledné rozlišování tohoto pojmu jako suverenity v ústavněprávním pojetí (v pozitivně-právním pojetî) a suverenity jako meta-konceptu, jenž je v právní doktríně možné nalézt. ${ }^{14}$

Co chápání suverenity jako meta-konceptu znamená? Jak bylo uvedeno výše, suverenita může být z obecného hlediska chápána ve dvou významech - jeden je ve významu pozitivního práva, kdy soudy a právní dokumenty referují o suverenitě, ten druhý ve významu, jakém o suverenitě hovoří právní teoretici a ústavní právníci v kontextu státovědy a vědy o ústavním právu ${ }^{15}$. Dle Michela Tropera je druhý význam meta-konceptem ${ }^{16}$. Troper dále pokračuje, že tyto dva pojmy jsou na sobě nezávislé, přičemž jejich rozlišování je důležité nejen s ohledem na fakt, že jsou používána na zcela jiné úrovni, ale jedná o dva zcela jiné koncepty (jedná se o zcela jiné diskurzy) ${ }^{17}$. Podle slovníku Oxford Reference je pojmem „meta“ označení pro předložku, jež se umíst’uje před slovo, jež opisuje vlastnosti původního slova ${ }^{18}$. Pokud tedy bude práce pracovat se suverenitou jako s meta-konceptem, bude pojednávat o konceptuálních východiscích popisujících samotný koncept suverenity.

Oproti tomu druhé chápání suverenity dle Troperova rozdělení je popis samotného chápání suverenity uvnitř systému konkrétního právního řádu, v př́padě této práce v rámci českého ústavního pořádku. Zjednodušeně řečeno můžeme říci, že pojednání o suverenitě jako meta-konceptu je pojednáním teoretickým a abstraktním a jako takové představuje obecná východiska dalších úvah, jež jsou činěny ve vztahu k ústavnímu pořádku České republiky, které je pak obsahem pojednání o suverenitě jako takové.

Suverenitu ve státovědném pojetí (jako meta-konceptu) lze chápat jako vlastnost státní moci ${ }^{19}$, která popisuje povahu této moci činit finální rozhodnutí, jež nepodléhají ničemu jinému, než této moci. Jedná se o nezávislost na jiné vyšší mocii ${ }^{20}$ Suverénní je taková moc, která nepodléhá žádné další moci a je ve svém rozhodování autonomní.

Samostatné pojednání je dále nutné věnovat tomu, jak je chápána suverenita uvnitř víceúrovňových systémů vládnutí, jakým je např́iklad Evropská unie. Vývoj EU ve vztahu $\mathrm{k}$ suverenitě je $\mathrm{v}$ teorii práva $\mathrm{EU}$ (můžeme říci $\mathrm{v}$ ústavním právu EU) značně

14 ROSENFELD, SAJÓ (eds.), op. cit., s. 352.

15 ROSENFELD, SAJÓ (eds.), op. cit., s. 352.

16 ROSENFELD, SAJÓ (eds.), op. cit., s. 352.

17 ROSENFELD, SAJÓ (eds.), op. cit., s. 352.

18 Oxford University Press's Dictionaries, Companions and Encyclopedias, Oxford Reference. Dostupné z: http://www. oxfordreference.com/view/10.1093/oi/authority.20110803100152644

19 HOLLÄNDER, Pavel. Základy všeobecné státovédy. 3. vyd., (Ve Vydavatelství a nakladatelství Aleš Čeněk 2. vyd.). Plzeň: Vydavatelství a nakladatelství Aleš Čeněk, 2012. ISBN 978-80-7380-395-7, s. 80 a násl. Georg Jellinek ve své všeobecné státovědě pojedná o suverenitě v rámci Hlavy čtrnácté: Vlastnosti státní moci, JELLINEK, G. V šeobecná státovéda. Praha: Jan Leichter, 1906, s. 457-534.

20 MEYER, ANSCHÜTZ, 2015, op. cit. s. 21. 
problematický, kdy není jasné, nakolik je vývoj EU obratem v mezinárodním právu²1, a nakolik je vůbec relevantní o suverenitě ve vztahu k právu EU přemýšlet ${ }^{22}$. Jiří Přibáň dokonce hovoří o post-suverénní „nové“ Evropě23.

Naše současné chápání pojmu suverenita totiž není založeno na zelené louce. Georg Jellinek ve své $V$ šeobecné státovédě na úvod kapitoly o suverenitě konstatoval, že „u žádnébo základního pojmu státoprávního neni vice zapotrebi poznáni dějinný jeho vývoj, nežli u pojmu suverenita. " 24

Revolučnost Jellinekova pojetí suverenity spočívá ve faktu, že suverenitu chápe jako historický koncept ${ }^{25}$. Ostatně ve $V$ šeobecné státovédě ze všeho nejdříve podává velmi podrobný a obsáhlý výčet předchozích přístupů a chápání pojmu suverenita, jež dle něj slouží k pochopení toho, co suverenita vlastně znamená, respektive znamenala. Jellinek přímo konstatuje, že suverenita není kategorií absolutní, ale kategorií historickou ${ }^{26}$.

Tento př́istup k chápání suverenity je velmi důležitý, jelikož pomůže pochopit, že suverenita není kategorií danou, nejedná se o nic, co by bylo možné identifikovat a roztř́ídit. Naopak, suverenita a její vývoj jsou těsně spjaty se státem, se státní mocí a s konkrétními představiteli států, přičemž historicky se význam suverenity měnil.

\section{Analýza relevantní rozhodovací praxe Ústavního soudu}

Následující pojednání si klade za cíl pojednat o problematice suverenity v rozhodovací praxi Ústavního soudu ve vztahu ke vztahu České republiky jako členského státu Unie a Unie samotné ${ }^{27}$.

Pokud ve vyhledávacím modulu Ústavního soudu NALUS ${ }^{28}$ zadáme heslo „suverenita“ do fulltextového vyhledávání a zároveň vyloučíme z vyhledávání rozhodnutí s předmětem řízení „závazky z komunitárního a unijního práva EU“, objevíme celkem 54 rozhodnutí,

21 ROSENFELD, SAJÓ (eds.), op. cit., s. 361.

22 SCHÜTZE, Robert. From dual to cooperative federalism: the changing structure of European law. 1st pub. Oxford: Oxford University Press, 2009, xxxvi, 391 s. Oxford studies in European law. ISBN 9780199664948, s. 30 a násl.

23 PŘIBÁŇ, 2015, op. cit.

24 JELLINEK, 1906, op. cit., s. 457.

25 JELLINEK, 1906, op. cit., s. 515.

26 JELLINEK, 1906, op. cit., s. 501.

27 Obecně se vztahem práva EU a právního řádu České republiky z monografií v českém právním prostředí zabývá především kniha BOBEK, Michal, Petr BŘIZA a Jan KOMÁREK. Vnitrostátni aplikace práva Evropské unie. Praha: C. H. Beck, 2011, xxvii, 606 s. Beckova edice právo. ISBN 978-807-4003-776; z dalších prací zmiňujeme diplomovou práci Heleny Bončkové - BONČKOVÁ, Helena. Recepce primátu práva Evropské unie / Evropského společenstvi českými vysokými soudy. Brno, 2010. Dostupné z: https://is.muni.cz/ auth/th/170111/pravf_m/. Diplomová práce. Právnická fakulta Masarykovy univerzity. Vedoucí práce Filip Křepelka; ve vztahy k předběžné otázce pak kniha Michala Bobka - BOBEK, Michal. Prédběžná otáżka v komunitárnim právu. Praha: Linde, 2005, xlv, 517 s. ISBN 80-720-1513-3.

28 Http://nalus.usoud.cz/Search/Search.aspx 
která nějakým zpo̊sobem pojednávají o problematice suverenity ve vztahu k České republice $^{29}$. Většinu těchto rozhodnutí představuje pojednání o projevu suverenity ve vztahu k extradičnímu rrízení, popř́padě pojednávají o suverenitě lidu ve vztahu k volebnímu právu.

Rozhodnutí, která pojednávají o suverenitě a jako předmět řízení mají závazky z komunitárního a unijního práva EU je celkem šest z celkových 46 rozhodnutí, jejichž předmětem jsou závazky z komunitárního a unijního práva EU. Tato čísla ukazují, že problematika suverenity není alespoň kvantitativně tím nejdůležitějším, co Ústavní soud ve vztahu k právu EU rozhoduje. Právě oněch šest rozhodnutí představují podstatný prvek, který nám pomůže pochopit př́stup Ústavního soudu k pojmu suverenity a její role ve vztahu EU a České republiky jako jejího členského státu. Dále se proto zaměříme na teoretickou reflexi tohoto vztahu v odborné literatuře a na úlohu, kterou Ústavní soud suverenitě přisoudil právě v těchto šesti podstatných rozhodnutích.

Česká republika v roce 2004 naskočila do jedoucího vlaku evropské integrace. Problematika vztahu práva EU a právních řádů členských států byla již v rámci teoretické debaty ve starých členských státech hojně řešena, a proto i na poli českého ústavního práva proběhla debata o tom, jak bude tento vztah vypadat v souvislosti s Českou republikou, již před vstupem do EU.

První vlnu teoretické reflexe postavení ČR k unijnímu právu vůbec vyvolala rozsáhlá novelizace Ústavy, která byla provedena ústavním zákonem č. 395/2001 Sb., pro kterou se vžil název Euronovela ${ }^{30}$ a její následná reflexe Ústavním soudem ${ }^{31}$. Většina debaty se týkala otázek obecného mezinárodního práva a především postavení zvláštní kategorie smluv o lidských právech ${ }^{32}$. Tyto úvahy tak nejsou pro naši analýzu podstatné.

V judikatuře Ústavního soudu máme čtyři velké milníky v př́stupu k právu Evropské unie, kterých se nepřekvapivě týká i šest stěžejních judikátů ve vztahu k suverenitě. Jsou jimi judikatura ve věci tzv. cukerných kvót ${ }^{33}$ [zde se o suverenitě hovoří v nálezu Pl. ÚS. 50/04 ze dne 8. 3. 2006 (154/2006 Sb., N 50/40 SbNU 443), Cukerné kvóty III. „Potud,

29 Celkem takto nastavená kritéria vyhledají 73 rozhodnutí, autor je však ročně roztřídil a vyřadil rozhodnutí, která nepojednávají o suverenitě ve vztahu k suverenitě státu, ale pojednávají o suverenitě ve vztahu k něčemu jinému, popř́padě pojednávají o politické straně, v jejímž názvu je slovo suverenita.

30 Podrobněji KYSELA, Jan a Zdeněk KÜHN. Aplikace mezinárodního práva po přijetí tzv. euronovely Ústavy ČR. Právni roz̧ledy, roč. 2002, č. 7 a literatura zde uvedená.

31 Především nález Ústavního soudu ze dne 25. 6. 2002, sp. zn. Pl. ÚS. 36/01, 403/2002 Sb., N 80/26 SbNU 317.

32 Především v souvislosti s júž zmiňovaným nálezem Ústavního soudu č. 403/2002 Sb. Podrobně FILIP, Jan. Nález č. 403/2002 Sb. jako rukavice hozená ústavodárci Ústavním soudem. Právní zpravodaj, roč. 2002, č. 11; KYSELA, Jan a Zdeněk KÜHN. Euronovela Ústavy ve světle překvapivého nálezu Ústavního soudu č. 403/2002 Sb. Soudní roz̧ledy, roč. 2002, č. 12.

33 Zde patří nález Pl. ÚS 45/2000 ze dne 14. 2. 2001 (96/2001 Sb., N 30/21 SbNU 261), Cukerné kvóty I., nález Pl. ÚS. 39/01 ze dne 30. 10. 2002 (499/2002 Sb., N 135/28 SbNU 153), Cukerné kvóty II. A nález Pl. ÚS. 50/04 ze dne 8. 3. 2006 (154/2006 Sb., N 50/40 SbNU 443), Cukerné kvóty III. „Potud, pokud“. 
pokud“ (dále citován jako „Cukerné kvóty III.“)], judikatura ve věci tzv. eurozatykače ${ }^{34}$ [zde se o suverenitě hovoří v nálezu Pl. ÚS. 66/04 ze dne 3. 5. 2006 (434/2006 Sb., N 93/41 SbNU 195), Evropský zatýkací rozkaz (eurozatykač), dále citováno jako „nález eurozatykač'], nálezy ve věci přezkumu Lisabonské smlouvy ${ }^{35}[$ zde se o suverenitě hovoří v nálezech Pl. ÚS. 19/08 ze dne 26. 11. 2008 (446/2008 Sb., N 201/51 SbNU 445), Lisabonská smlouva pozměňující Smlouvu o Evropské unii a Smlouvu o založení Evropského společenství (dále citován jako „Lisabon I.“) a Pl. ÚS. 29/09 ze dne 3. 11. 2009 (387/2009 Sb., N 233/55 SbNU 197), Lisabonská smlouva pozměňující Smlouvu o Evropské unii a Smlouvu o založení Evropského společenství II (dále citován jako „Lisabon II. “)] a velmi kontroverzní rozhodovací praxe Ústavního soudu ve věci tzv. „slovenských důchodů “36 [zde se o suverenitě hovoří v nálezu Pl. ÚS. 5/12 ze dne 31. 1. 2012 (N 24/64 SbNU 237) Slovenské důchody XVII - aplikace Smlouvy mezi ČR a SR o sociálním zabezpečení č. 228/1993 Sb. a v usnesení IV.ÚS 3400/11 ze dne 19. 6. 2012 Slovenské důchody XX - aplikace Smlouvy mezi ČR a SR o sociálním zabezpečení].

Pro pochopení prrístupu Ústavního soudu k problematice vztahu EU a České republiky jako členského státu a role suverenity v tomto pojetí je potřeba blíže pojednat o výše uvedených judikátech, které nám identifikují ty situace, ve kterých Ústavní soud problematiku suverenity a vztahu práva EU nějakým zpơsobem řešil.

Jako první se proto zaměříme na reflexi problematiky cukerných kvót ze strany Ústavního soudu. Př́stup Ústavního soudu ve věci cukerných kvót se setkal s bouřlivou kritikou ze strany akademické obce ${ }^{37}$. Ústavní soud zde vyšel z prŕístupu k právu EU, který volil

34 Nález Pl. ÚS. 66/04 ze dne 3. 5. 2006 (434/2006 Sb., N 93/41 SbNU 195), Evropský zatýkací rozkaz (eurozatykač).

35 Nález Pl. ÚS. 19/08 ze dne 26. 11. 2008 (446/2008 Sb., N 201/51 SbNU 445), Lisabonská smlouva pozměňující Smlouvu o Evropské unii a Smlouvu o založení Evropského společenství (dále citován jako „Lisabon I.“) a nález Pl. ÚS. 29/09 ze dne 3. 11. 2009 (387/2009 Sb., N 233/55 SbNU 197), Lisabonská smlouva pozměňující Smlouvu o Evropské unii a Smlouvu o založení Evropského společenství II (dále citován jako „Lisabon II.“).

36 Problematika vývoje důchodů v nástupnických republikách je podrobně popsána v článku Filipa Křepelky, KŘEPELKA, Filip. „Českoslovenšti““ důchodci v pasti práva Evropské unie. Časopis pro právni védu a praxi, roč. 2011, č. 2. O judikatuře Ústavního soudu v této věci pak více KNOB, Miroslav. Rozpad federace jako specifický prvek práva Evropské unie (slovenské důchodu v judikatuře Ústavního soudu). In: Dny práva 2012 - Days of Law 2012. Brno: Masarykova univerzita, Právnická fakulta, 2013, s. 389-405. Spisy Právnické fakulty Masarykovy univerzity, řada teoretická, sv. č. 442. ISBN 978-80-210-6319-8.

37 Např. Jiř́ Malenovský ve svém článku MALENOVSKÝ, Jiří. 60 let Evropských společenství: od francouzského „supranacionálního“ smluvního projektu k jeho německému „podústavnímu“ provádění. Právník, roč. 2012, č. 7, s. 673-722; dále pak MALENOVSKÝ, Jiří. K nové doktríně Ústavního soudu ČR v otázce vztahů českého, komunitárního a mezinárodního práva. Právní roz̧bledy, roč. 2006, č. 21, s. 774; KRÁL, Richard. Uznání i rozpaky nad „komunitárním“ nálezem Ústavního soudu ve věci cukerných kvót. Právní roz̧hledy, roč. 2006, č. 11, s. 413; MARŠÁLKOVÁ, Zuzana. Jak daleko sahá omezení pravomocí orgánů ČR po vstupu do EU ve světle nálezu Ústavního soudu ve věci cukerných kvót? Právní roz̧bledy, roč. 2006, č. 15, s. 556; KÜHN, Zdeněk. Rozšírení Evropské unie a vztah šestadvaceti ústavních systémů. Právník, roč. 2004, č. 8., s. 768; a shrnutí problematiky nálezu Cukerné kvóty III v BOBEK, Michal, Petr BŘÍZA a Jan KOMÁREK. Vnitrostátní aplikace práva Evropské unie. Praha: C. H. Beck, 2011, xxvii, 606 s., s. 454 a násl. Beckova edice právo. ISBN 978-807-4003-776. 
německý Spolkový ústavní soud. Ústavní soud přišel s teorií propůjčení pravomocí Unii a jejich př́padného zpětvzetî̉ ${ }^{8}$ na základě narušení materiálního jádra Ústavy. Vymiňuje si tedy možnost konstatovat, kdy jednají orgány Unie ultra vires (kdy zasahují do oblastí, které jim nepř́sluší či do materiálního ohniska Ústavy). Ústavní soud se v judikatuře k cukerným kvótám prriklonil k názoru, že čl. 10a má i recepční i kompetenční povahu a že ona brána může být i uzavřena, pokud bude Evropská unie jednat ultra vires ${ }^{39}$.

K suverenitě Ústavní soud v nálezu Cukerné kvóty III. hovoří o suverenitě ve vztahu k přenosu pravomocí na orgány EU, kdy Ústavní soud konkrétně uvádí, že ,propiijčení části pravomocí je ovšem podle Ústavního soudu propijičením podminèným, nebot' originárním nositelem suverenity a z ni vyplývajicich pravomoci nadále quistala Ceská republika. "Ústavní soud dále konstatuje, že „[o]na podminènost delegace těchto pravomocí se podle Ústavního soudu projevije ve dvou rovinách: v rovinè formálni a v rovinè materiální. První z těchto rovin se týká samotných mocenských atributu státni surchovanosti, drubá rovina se týká obsahových komponent výkonu státni moci. Jinak. rèreno, delegace ćásti pravomoci vnitrostátnich orgánu mùze trvat potud, pokud tyto pravomoci jsou orgány ES vykonávány zpuisobem slučitelným s uchováním základů státni suverenity České republiky a zpuisobem, jenž neobrožuje samotnou podstatu materiálního právního státu. "Závěr, který Ústavní soud na výše uvedených úvahách staví, je takový, že pokud by EU z takto nastavených mantinelů vykročila, tedy že by zasáhla do materiálního jádra Ústavy, jehož součástí je i suverenita, jednala by ultra vires.

Zajímavým prvkem v tomto rozhodnutí je fakt, že Ústavní soud spojuje problematiku suverenity s přenosem pravomocí na Evropskou unii a vyvozuje závěr, že suverenita slouží ve svém důsledku jako limitace pro tento přenos. Z pohledu Ústavního osudu je pak tato limitace podstatná jako rámec přezkumu, byt' v rámci kontextu celého materiálního jádra Ústavy ${ }^{40}$. Suverenita zde není prvkem tohoto přenosu, ale jeho limitací.

Ve stejném duchu se pak nese i odkaz na suverenitu ve věci nálezu eurozatykač. Ústavní soud zde znovu konstatuje, že suverenita jako jeden z prvků materiálního jádra Ústavy je jedním z limitujících prvků, které budou sloužit jako přezkumný rámec pro kontrolu souladu činnosti EU s ústavním pořádkem České republiky. Ústavní soud znovu potvrdil svůj náhled na suverenitu jako na součást referenčního rámce pro přenos pravomocí na Evropskou unii.

38 MALENOVSKÝ, 2012, op. cit.

39 Podrobný popis jednotlivých př́stupů a názorů na povahu čl. 10a je možné najít v BAHÝLOVÁ, FILIP, MOLEK, PODHRÁZKÝ, ŠIMÍČEK, VYHNÁNEK, 2010, op. cit., s. 203 a násl. (Komentár̆ Pavla Molka k čl. 10a Ústavy).

40 Zajímavá je také úvaha o suverenitě jako prvku zapříčiňující podmíněnost přenosu pravomocí. Tato úvaha je jistě ovlivněna kontextem doby, kdy tento nález Ústavní soud prijímal ještě před Lisabonskou smlouvou, která právně upravila vystoupení z Evropské unie. K problematice zpětvzetí pravomocí z EU na národní státy více ZBÍRAL, Robert. Prenos pravomocí členskéch státu na Evropskou unï: cesta bez. zpátečního listku? Praha: Leges, 2013. 
Nejvýznamnějšími judikáty ve věci vzájemného vztahu ČR a EU byly bezpochyby nálezy ohledně přezkumu Lisabonské smlouvy, tedy nálezy Lisabon I. a Lisabon II. Zde se Ústavní soud podrobně vypořádal s problematikou suverenity, což bylo dáno především skutečností, že argumentace zachováním suverenity byla jedním z tvrzených nesouladů Lisabonské smlouvy s českým ústavním pořádkem. Tyto judikáty byly podrobně rozebrány jak v knize Pavla Molka ${ }^{41}$, tak v dalších textech z oblasti ústavního práva ${ }^{42}$. Ve stručnosti je však potřeba zopakovat základní tezi o suverenitě, kterou Ústavní soud ve svých nálezech postuloval. Ačkoliv se tyto teze mohou zdát banální, či všeobecně známé na poli ústavního práva, jedná se, jak vyplývá z analýzy judikatury Ústavního soudu výše, o jediné zachycení problematiky suverenity ve vztahu k právu EU, která se v rozhodovací praxi českého Ústavního soudu nachází. Konkrétně Ústavní soud v nálezu Lisabon I. konstatoval následující:

„104. Evropská unie pokročila zdaleka nejvíce v konceptu sdillené - „slité“suverenity (pooled sovereignty) a již dnes vytvář́ entitu sui generis, která té̌̌ ko snese zarazeni do klasických státovédných kategorii. Je spišse otázkou jazykovou, zda lze proces integrace označovat za ,ztrátu“ č́sti suverenity, resp. kompetencí, nebo přiléhavěji nap̌̌. za „propůjčení, postoupeni" části kompetencí suveréna. Mư̌̌e se jevit jako paradoxni, že klićcovým projevem svrchovanosti státu je i možnost se svou svrchovaností (její cástí) dále nakládat, resp. určité kompetence dočasně či trvale postoupit.

(...)

108. Z uvedených úvah lze tedy dovodit, že prenesení určitých kompetencí státu, které vyvěrá ze svobodné vůle suveréna a bude nadále vykonáváno za jeho účasti předem dohodnutým, kontrolovaným zpưsobem, není pojmovým oslabením svrchovanosti, ale může naopak ve svých dissledcích znamenat její posílení ve společném postupu integrovaného celku. Integračni proces EU se nedèje radikálnim zpiisobem, který by obecně znamenal „ztrátu“ národni suverenity, nýbř̌ jde o proces evolučni, a - kromé jïnébo - i o reakci na postupující globalizaci ve svétè. "43

Úvodní teze citované části nálezu Lisabon I. by naznačovala, že Ústavnímu soudu je vlastní pojetí „sliti““ či „sdíleni““ suverenity. Ústavní soud však následně konstatuje, že na EU je část suverenity „přenášena“, tedy že Česká republika část své suverenity přenáší na EU, kterou Ústavní soud chápe jako entitu sui generis. Ústavní soud tedy znovu suverenitu chápe pouze jako rámec pro přenos pravomocí na orgány Evropské unie - respektive, chápe tento přenos jako projev této suverenity, která je pro něj zároveň limitující. V tomto kontextu tak Ústavní soud v podstatě navázal na svoje předchozí závěry ohledně suverenity, respektive je rozvedl a zasadil do teoretického rámce pojetí suverenity.

\footnotetext{
41 MOLEK, 2014, op. cit., s. 234 a násl.

42 Nejnověji tak činí Jiří Přibáň v PŘIBÁŇ, 2015, op. cit.

43 Lisabon I., zvýraznění Miroslav Knob.
} 
Nález Lisabon II. pak na toto pojetí odkázal a v reakci na konkrétní námitky prezidenta republiky vypořádal další dílčí změny, které přináší Lisabonská smlouva jako souladné s tímto pojetím státní suverenity. Suverenita je tedy již konstantně chápána jako mantinel pro přenos pravomocí na Evropskou unii.

Dovedení významnosti prvku přenosu pravomocí a suverenity jako jejího mantinelu do důsledků představuje notoricky známá kauza „slovenských důchodư‘ “44, především rozhodnutí Ústavního soudu v kauze „Holubec“, které se setkalo s bouřlivým ohlasem na poli ústavněprávní teorie ${ }^{45}$. Ústavní soud zde konstatoval, že Evropská unie (respektive Soudní dvůr Evropské unie) zde vykročil z rámce pravomocí mu svěřených Českou republikou. Jednoznačně tak postuloval, že existují mantinely přenášení pravomocí na Evropskou unii. A pokud EU vykročí ze svých mantinelů, je zde Ústavní soud, který ohlídá suverenitu České republiky, respektive materiální ohnisko Ústavy, jehož je suverenita součástí.

Ústavní soud ve své rozhodovací praxi potvrdil výše uvedené teoretické závěry o povaze suverenity České republiky jako omezené. Respektive, Ústavní soud jasně aproboval, že proces „vzdávání se suverenity“ (její přenos na Evropskou unii) je jedním z prvků její realizace, přičemž realizace tohoto přenosu se děje na základě přenosu pravomocí a materiální ohnisko Ústavy (a suverenita jako jeho součást) je jeho limitací.

\section{Závěr}

Z výše uvedené analýzy rozhodovací praxe Ústavního soudu plyne, že Ústavní soud se $\mathrm{k}$ problematice suverenity ve vztahu $\mathrm{k}$ EU vyjadřoval v menšině rozhodnutí, které se nějakým způsobem dotýkají problematiky práva EU (6 ze 46). Kvantitativně se tedy jedná o menšinu rozhodnutí. Kvalitativně tomu tak již není. Všechna rozhodnutí, která zmiňují suverenitu ve vztahu k právu EU, jsou rozhodnutími, která jsou pro tento vztah určující a která představují mezníky v rozhodovací praxi Ústavního soudu ve vztahu

44 Ke genezi této justiční ságy viz KNOB, Miroslav. Rozpad federace jako specifický prvek práva Evropské unie (slovenské důchodu v judikatuře Ústavního soudu). In: Dny práva 2012 - Days of Law 2012. Brno: Masarykova univerzita, Právnická fakulta, 2013, s. 389-405. Spisy Právnické fakulty Masarykovy univerzity, řada teoretická, sv. č. 442. ISBN 978-80-210-6319-8.

45 KOMÁREK, Jan. V Joštové vybuchla atomová bomba. Jiné právo [online]. 15. 2. 2012 [cit. 2016-01-11]. Dostupné z: http://jinepravo.blogspot.com/2012/02/v-jostove-vybuchla-atomova-bomba.html; KOMÁREK, Jan. Playing With Matches: The Czech Constitutional Court's Ultra Vires Revolution. Verfassungsblog [online]. 22. 2. 2012 [cit. 2016-01-11]. Dostupné z: http://verfassungsblog.de/playing-matches-czech-constitutional-courts-ultra-vires-revolution/; BOBEK, Michal. ... a Ústavní soud skočil. Lidové noviny, Praha: Lidové noviny, 20. 2. 2012. ISSN 0862-5921; MOLEK, Pavel. The Court That Roared: The Czech Constitutional Court Declaring War of Independence against the ECJ. European Law Reporter, roč. 2012, č. 6, s. 162-170; KǨEPELKA, Filip. Imperfect Dismantlement of Czechoslovak Pension System as Impulse for Rebellion against Law of the European Union. European Journal of Social Rights, roč. 2012, č. 4; KNOB, Miroslav. Další pokračování ságy slovenských důchodů před Ústavním soudem. Soudni roz̧bledy, roč. 2012, č. 4, s. 127. 
k právu EU. Ač tedy kvantitativně minoritní, významově se jedná o velmi důležitá rozhodnutí. Je však otázkou, jakou roli suverenita v tomto př́stupu opravdu sehrává.

Obsahově můžeme $\mathrm{v}$ analyzovaných šesti rozhodnutích hovořit o ustálené rozhodovací praxi, co se týče faktoru suverenity ve vztahu k právu EU a vztahu České republiky k Unii. Ústavní soud chápe suverenitu jako složku materiálního jádra Ústavy. V tomto kontextu lze říci, že ji pojímá stejně jako Pavel Molek. Materiální jádro Ústavy (a suverenitu výslovně) chápe jako mantinel pro přenos pravomocí na Evropskou unii, respektive, s ohledem na nález Lisabon I. chápe tento přenos jako projev suverenity České republiky a zároveň jeho limitaci.

Co nám tento závěr říká k základní otázce v nadpisu článku? Je zkoumání role suverenity pro analýzu vztahu Evropské unie a České republiky, jako jejího členského státu, slepou větví, nebo odrazovým můstkem? Je suverenita prvek, který je potřeba pro analýzu tohoto vztahu zkoumat a brát v úvahu pro další závěry, nebo nás přemýšlení o suverenitě zavede do slepé uličky?

Pokud se podíváme, jak suverenitu pojímá Ústavní soud, můžeme říci, že platí spíše druhá z hypotetických odpovědí. Pokud je suverenita, jako jeden z prvků materiálního jádra Ústavy, mantinelem, který limituje přenos pravomocí na Evropskou unii ze strany České republiky, pro samotný proces přenosu, na základě kterého se toto vymezení děje, nemá valný vliv. Suverenita podle Ústavního soudu představuje velmi nejasnou a ve své podstatě také plastickou hranici.

Úvahy o suverenitě nám možná pomohou v rámci teoretické reflexe konkretizovat tuto hranici, avšak pro pochopení a analýzu současného stavu EU a České republiky nám př́liš užitečné nebudou. Suverenita ve státovědném pojetí je navíc kategorií značně nejasnou, která je definována spíše svým historickým kontextem, než aby byla kategorií přesně danou a judikaturně definovanou, přičemž suverenita je z hlediska jejîho pojetí v rámci ústavního pořádku České republiky definována velmi vágně.

Pokud se pozorně podíváme na rozhodovací praxi Ústavního soudu ve vztahu k suverenitě, můžeme dokonce uvést, že v kontextu vztahu České republiky a EU se Ústavní soud dopouští definice kruhem - suverenita je základní prvek přenosu pravomocí na EU a zároveň její limitací. Pokud chceme pochopit a analyzovat vztah České republiky a Evropské unie, jsou úvahy o roli suverenity spíše slepou větví našich úvah, než odrazovým můstkem. Analýza pojmu suverenity, respektive jejího obsahu (suverenita v pozitivně-právním pojetî) nám může pomoci definovat velmi nejasnou hranici tohoto přenosu, avšak o povaze vztahu nám moc neřekne. Podstatným prvkem pro vymezení podoby tohoto vztahu je přenášení jednotlivých pravomocí na Evropskou unii, jejich způsob a podoba. Definice a vymezení obsahu pojmu suverenity v českém ústavním pořádku nám pomůže identifikovat hranici pro přenos těchto pravomocí. Respektive pomůže ním stanovit (velmi nejasně) potenciální limity, avšak při praktickém vymezení 
současné podoby tohoto vztahu nás zavede do slepé uličky, kdy namísto obsahu vztahu Evropské unie a České republiky jako jejího členského státu budeme zkoumat jeho limity.

Logickým východiskem pro další úvahy se proto jeví chápání tohoto vztahu na poli vymezení obsahu přenosu pravomocí. Pokud se má akademické bádání ve vztahu práva EU a členských států EU ubírat smysluplným směrem, je to směr analýzy přenosu pravomocí z členského státu na EU (respektive i opačným směrem v př́padě zpětného přenosu pravomocí z Unie na členské státy). Další zkoumání by se tak mělo ubírat směrem $\mathrm{k}$ analýze toho, jaký tento vztah je. Prvek suverenity je pro pochopení obsahu tohoto vztahu nepodstatný. Pro výzkum, který se však zaměří na to, jaké jsou teoretické limity tohoto vztahu je však prvek suverenity relevantním okruhem zájmu. 